\title{
Keratosis spinulosa developing in borderline-tuberculoid lesions during type I lepra reaction: two case reports
}

\author{
T P THANKAPPAN \& G SULOCHANA \\ Medical College Hospital, Alleppey 688 011, South India
}

\begin{abstract}
Accepted for publication 4 June 1990
Summary Two cases of borderline-tuberculoid leprosy which developed keratosis spinulosa over the anaesthetic areas alone during type I lepra reactions are described. Both patients only developed spiny papules during the period of reaction and subsided with control of the reaction. The probable mechanism of this peculiar phenomenon might be due to the generation of epidermal growth factors by local $\mathrm{T}$ cell activation during the type I lepra reaction.
\end{abstract}

Case 1

A 25-year-old male Indian manual labourer reported to the Dermatology OPD of our hospital with two hypopigmented lesions on the forearm and weakness of his right hand; these had been present for $1 \frac{1}{2}$ years and had not received treatment. On examination he had two well defined, hypopigmented, anaesthetic, hairless patches on the medial aspect of his right forearm, together with partial ulnar clawing and slight wasting of hypothenar muscles. The right ulnar nerve was thickened and tender. Skin smears from the lesions were negative, and biopsy showed well formed epitheloid granulomas surrounding dermal appendages with a free, narrow zone immediately beneath the epidermis. A diagnosis of borderline-tuberculoid (BT) leprosy was made, and treatment was instituted with rifampicin $600 \mathrm{mg}$ monthly and dapsone $100 \mathrm{mg}$ daily.

Ten days after the second dose of rifampicin the patient reported with severe pain over the ulnar nerve and increased weakness of the hand, together with development of spiny lesions over the two patches. The patches were erythematous, tender and mildly oedematous, and their surfaces were covered with minute spiny keratotic papules. Skin smear was negative for AFB, but we could not carry out a lepromin test. Biopsy showed marked hyperkeratosis with follicular plugging, oedema in upper and middermis, and tuberculoid granulomas concentrated mainly around hair follicles; these eroded the basal layer of epidermis. These findings confirmed a diagnosis of Type I lepra reaction (reversal) and prednisolone $80 \mathrm{mg}$ and clofazimine $300 \mathrm{mg}$ were added to rifampicin and dapsone. Pain and erythema subsided, and the papules disappeared by the end of three months. Prednisolone dosage was decreased, and stopped within a period of three months. Clofazimine was also decreased and reduced to $50 \mathrm{mg}$ within a period of 6 months and continued along with rifampicin and dapsone to complete one year. The patches remained quiescent, though anaesthetic, throughout the 16 months of follow-up. 


\section{Case 2}

A 35-year-old-Indian manual labourer presented with Type I lepra reaction, having received dapsone monotherapy from the local hospital for the previous six months. On examination he had a large patch over the left shoulder extending to the upper arm. It was well defined, erythematous and tender, and its surface was covered with spiny papules (Figure 1). A small macule on the left forearm had similar changes, and the left superficial peroneal nerve was thickened and tender; skin smear was negative. He was treated with prednisolone $40 \mathrm{mg}$, clofazimine $300 \mathrm{mg}$ and dapsone $100 \mathrm{mg}$ daily with rifampicin 600 mg once a month. The lesions improved dramatically and prednisolone was decreased and withdrawn over a period of three months, by which time the spiny papules and erythema has disappeared. Clofazimine was also reduced to $50 \mathrm{mg}$ and continued to complete six months and no recurrence of activity appeared over the next one year followup period.

No evidence of associated systemic disease was found in either of these two patients.

\section{Discussion}

Apart from the well known changes occurring in reactions we know of very few reports of complications specifically affecting leprosy skin lesions. There has been a report of vitiligo developing in the margins of two tuberculoid (TT) lesions, ${ }^{1}$ and another of comedones in

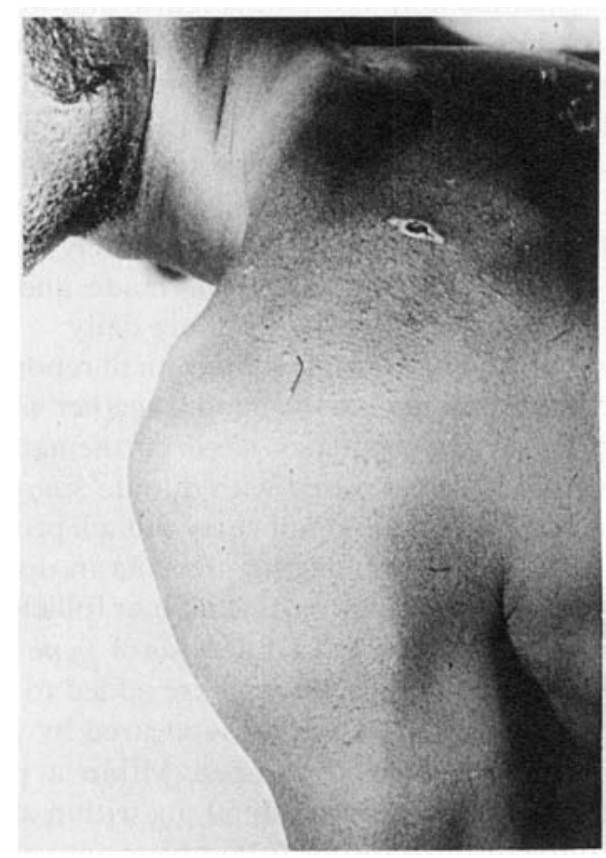

Figure 1 
BT lesions which had been massaged with coconut oil. ${ }^{2}$ Keratosis spinulosa developing in skin lesions of leprosy patients, whether in reactions or not, has not previously been reported. This dermatosis consists of minute follicular papules, each with a horny spine in the centre, grouped in plaques and developing on various sites. This skin reaction has been reported in lichen scrofulosorum, in cutaneous mycoses, in miliary papular syphilis and occasionally in drug reactions, subsiding spontaneously after a few months. ${ }^{3}$ The fact that in our patients it was confined to the patches of BT leprosy during Type I reaction suggests that it was a clinical manifestation of an immune reaction in the skin. Type I reaction (reversal) is an example of delayed type hypersensitivity (DTH), ${ }^{4}$ and Kaplan et al. ${ }^{5}$ have investigated epidermal changes in other examples of DTH such as the tuberculin reaction and the reaction when antigen is injected intradermally into skin lesions of tuberculoid (BT and TT) leprosy patients. They found marked thickening of epidermis associated with both the size and the number of keratinocytes increasing, together with changes in keratinocyte Ia-antigen expression in the epidermis. These authors suggest that one or more epidermal growth factors may be generated in the course of a delayed immune reaction in the dermis. Thangaraj et al. ${ }^{6}$ have demonstrated significant epidermal changes in lesions of leprosy patients undergoing Type I (reversal) reactions in the form of increase in epidermal cell layers, the consistent presence of Ia in all keratinocytes, an increase in Langerhan's cell numbers, and scattered $T$ cells within the epidermis. Their studies indicate that local $\mathrm{T}$ cell activation can lead to the production of lymphokine, such as gamma-interferon (interferon) with subsequent induction of Ia on epidermal cells, constituting an important event in reactional leprosy patients. In the light of these observations it is hardly surprising that a clinical epidermal change, such as keratosis spinulosa, should occur as a manifestation in Type I lepra reaction, and we wonder why it has not been reported before now.

\section{References}

1 Misra RS, Jain RK, Mukherjee A. Vitiligo on tuberculoid patches-a case report. Ind J Lepr, 1984 56(3): 65861.

2 Srinivas CR, Padhee A, Balachandran C, Shenoy SD, Acharya S, Ramnarayan K. Comedones induced by coconut oil in borderline tuberculoid lesion. Int J Lepr, 1988; 56(3): 471-2.

${ }^{3}$ Ebling FJG, Marks R, Rook A. Disorders of keratinization. In: Text Book of Dermatology, 4th ed. Rook A, Wilkinson DS, Ebling FJG, Champion RH, Burton JL (eds). Oxf ord: Blackwell Scientific Publications, 1986, 1437-8

4 Jopling WH, McDougall AC. Handbook of Leprosy. Oxford: Heinemann Professional Publishing, 1988.

${ }_{5}^{5}$ Kaplan G, Witmer MD, Nath I et al. Proc Natl Acad Sci USA, 1986; 83: 3469-73.

6 Thankaraj H, Laal S, Thankaraj I, Nath I. Epidermal changes in reactional leprosy: Keratinocyte Ia expression as an indicator of cell-mediated immune response. Int $J$ Lepr, 1988; 56(3): 401-7. 
Développement de kératose épineuse dans des lésions des cas limites tuberculoides dans des réactions de lepre du type I: rapport de deux cas

\title{
T P THANKAPPAN ET G SULOCHANA
}

Sommaire - On décrit deux cas limites de lèpre tuberculöide avec développement de kératose épineuse limité aux zones anesthésiques dans des réactions de lèpre du type I. Les deux patients ont développé des papules épineuses seulement pendant la période de réaction et qui ont disparues avec la mise sous contrôle de la réaction. Le méchanisme probable de ce phénomène étrange peut être dû à la production des facteurs de croissance épidermiques par l'activation des lymphocytes-T pendant la réaction de lèpre du type $I$.

\section{Desarrollo de queratosis espinosa en lesiones tuberculoides inciertas en reacciones de lepra del tipo I: informe de dos casos}

\author{
T P THANKAPPAN Y G SULOCHANA
}

Resumen - Se describen dos casos inciertos de lepra tuberculoide con desarrollo de queratosis espinosa limitado a las zonas anestésicas en reacciones de lepra del tipo I. En los dos pacientes se desarrollaron pápulas espinosas sólo durante el periodo de reacción, que desaparecieron al controlarse la reacción. El mecanismo probable de este extraño fenómeno puede ser debido a la producción de factores de crecimiento epidérmicos por activación de linfocitos-T durante la reacción de lepra del tipo I. 